\title{
Addressing equity in community forestry: lessons from 20 years of implementation in Cameroon
}

\author{
Urcil Papito Kenfack Essougong ${ }^{1}$, Divine Foundjem-Tita ${ }^{2}$ and Peter A. Minang ${ }^{3}$
}

\begin{abstract}
A community forestry approach was adopted by Cameroon as a strategy to promote the sustainable management of forests, participation by local communities in forest management, and poverty alleviation. However, results have been moderate and community forestry has largely failed in achieving its initial goals. Our work, based on existing literature, uses the three inter-related dimensions of equity: distributive, procedural, and contextual to highlight the main equity challenges encountered in implementing the community forestry approach over the past 20 years in Cameroon. The main constraints to distributive equity identified include: the absence of clear benefit-sharing mechanisms and rents capture by elites, insecure tenure, and limited use rights of forest resources. Regarding the procedural dimension, we observed an exclusion of vulnerable groups, especially women, and a lack of information flow and transparency in decision-making processes. Finally, for contextual equity, the main constraints are unfair laws and regulations that give more advantages to the state and logging companies than to the local population. Moreover, poor community capacities and high transaction costs in the process of obtaining and exploiting community forests are additional constraints to contextual equity. The authors recommend a few measures to improve community forestry contribution to socioeconomic development, equity in benefit sharing, and sustainable management of forest resources. These include the need: (1) to promote transparency in community forests management with fair and gender-based policies that consider socioeconomic differences existing within and between forest communities; (2) to strengthen local community members financial and technical capacities and increase their representation and participation in decision-making structures; and (3) to set up mechanisms that guarantee existing policies are fully implemented.
\end{abstract}

Key Words: benefit sharing; decentralization; fairness; forestry governance; natural resources management; participation; sustainability

\section{INTRODUCTION}

About $20 \%$ of the global population depends on forests for employment, forest products livelihoods, and incomes (World Bank 2016). Approximately $75 \%$ of poor people that live in rural areas are forest-dependent people (IFAD 2004). Moreover, about $83 \%$ of the extreme poor living in developing countries depend on forest resources for all or part of their livelihoods (Chao 2012). In Cameroon, the forest sector contributes to about $2.8 \%$ of the GDP (US\$695.3 million) and provides direct employment to 22,000 people (FAO 2014). Nkou and Atyi Eba'a (2013) estimated the number of people employed temporally or permanently in the sector at more than 2,478,880. Atyi Eba'a et al. (2016) also estimated that the firewood and charcoal subsector provide about 90,000 equivalent full-time jobs as well as US\$304 million, representing $1.3 \%$ of the GDP. Nontimber forests products (NTFPs) play a key role in the daily life of millions of people living in the rural areas of Cameroon. The collection and sales of NTFPs constitute an important source of food, cash (Lescuyer 2010, Awono et al. 2016), and employment for rural dwellers. This activity creates at least 283,000 direct and indirect jobs at various levels of the NTFPs value chain (Awono et al. 2016). Nevertheless, as in most countries of the Congo basin, logging remains the main provider of salaried jobs in the private sector. This is particularly true in remote forested rural areas in which logging companies commonly substitute the state in the provision of public services related to social development usually, in accordance with their tender specifications (Poufoun et al. 2013).

Although forests constitute an important asset for rural economy in Cameroon, the sector faces serious challenges related to environmental degradation, equity, and persistent poverty (Jum et al. 2007). Likewise, clear ownership, access, and management rights over forests are vital for good governance and sustainable management of the resources (World Bank 2016). Although most forests remain publicly owned (World Bank 2016), forest management by central governments has proven to be ineffective in providing key services and benefits to forest communities (Jum et al. 2007). Thus, there are increasing incentives from governments to entrust forest resources management to communities (Andersson et al. 2006, Parkins 2006). The expectation is that these communities will manage the forests in a more sustainable way and derive more environmental and socioeconomic benefits from them (Maryudi et al. 2012, World Bank 2016). Cameroon, with a large share of its land covered by forests, is not an exception to this global tendency.

During the colonial period and up to the mid-1990s, Cameroon's forests were managed through a centrally directed structure and process. The centralized structure expropriated and took over control of forest resources from local communities. This led to the situation whereby the latter communities were excluded from accessing forest resources and the economic benefits accruing from them (Ekoko 2000, Brown and Schreckenberg 2001). In the early 1990s, under pressure from the World Bank and other influential organizations (Ekoko 2000, Beauchamp and Ingram 2011), the country carried a series of macropolicy, sectoral and constitutional, reforms that affected all aspects of society, including the forest. This resulted in the enactment of the law No 94/01 establishing a forests, fauna, and fisheries system in January 1994, and later in August 1995, in the enactment of the decree No 95/531/PM laying down the procedure for implementing the forest's system (Republic of Cameroon 1995). The 1994 forest law

${ }^{1}$ Plant Production Systems, Department of Plant Sciences, Wageningen University, Wageningen, The Netherlands, ${ }^{2}$ World Agroforestry Centre, ICRAF-West and Central Africa Regional Programme, Yaounde, Cameroon, ${ }^{3}$ ASB Partnership for the Tropical Forest Margins and World Agroforestry Centre (ICRAF), Nairobi, Kenya 
led to a zoning of Cameroon's forests into two parts: the permanent forest domain (PFD) and the nonpermanent forest domain (NPFD; Oyono 2009, Cerutti et al. 2016). The PFD refers to all the forest space definitively assigned to "forest" and "wildlife habitat"; comprises forests strictly belonging to the state and registered in its name; and forests allocated to councils and registered as councils' private property (Oyono 2009, Cerutti et al. 2016, Merlet and Fraticelli 2016). The NPFD consists of forests located in the agroforestry band of the zoning plan and controlled by the forestry administration and includes portions of forest likely to be assigned to uses than other real forest and wildlife valorization (Oyono 2009, Cerutti et al. 2016). The NPFD includes community forests.

The decree of implementation of the 1994 Forestry Law defines a community forest as "a forest of the non-permanent forest estate, object of a management agreement between a village community and the service in charge of forestry. The management of such forests which should not exceed 5000 hectares is the responsibility of the village community concerned, with the technical assistance of the service in charge of Forestry" (Cuny 2011:5). Thus, the decree explicitly confers the management of the forest to the community. However, in practice, the constitution of a legal entity (associations, cooperatives, common initiative groups, and economic interest groups) is a prerequisite for a community to be allocated a community forest (Djeumo 2001, Merlet and Fraticelli 2016). These organizational forms are the legal entities owning the forest and in charge of its management. Nevertheless, these entities are governed by different laws, they depend on clearly defined ministries, and they were created to attain very specific objectives (Djeumo 2001). The forest management agreement is valid for 25 years renewable and based on a simple management plan that is updated every 5 years and defines how the forest resources will be exploited and the benefits used (Cuny 2011).

The community forestry approach has been implemented in Cameroon since 1995 (Auzel et al. 2001). It was designed as an option to enhance livelihood opportunities for rural populations and forest resources conservation through decentralized forest governance, generation of income, and empowerment of rural forest-dependent communities (Logo 2003, Cuny 2011). The community forestry approach in Cameroon is reported to have recorded some successes thanks to support from its technical and financial partners (Oyono et al. 2006, Cuny 2011, Collins and Tsanga 2016, Merlet and Fraticelli 2016). Despite the latter support and efforts by the government to develop the concept, its impact on local democracy, equity, living standards, poverty alleviation, social vulnerability, and environmental sustainability remains weak (Oyono et al. 2007). On the other hand, who gets what from community-based resources management as in community forestry is increasingly highlighted as a key issue in the international literature (Mahanty et al. 2006, McDermott 2009a, Maryudi et al. 2012, Turner et al. 2016). Wong et al. (2016) claimed that equity consideration in the design of policies regarding forest resource management can have a positive impact on the results of these policies. Consequently, equity can contribute to sustainable forest management and improve the redistribution of benefits provided by the forest among various stakeholders. However, in Cameroon, existing literature on community forestry does not pay enough attention to equity aspects such as inclusion and full participation of traditional users in the management and the distribution of benefits within communities. Thus, based on a review of relevant literature published and available in online databases such as Google Scholar and Web of Science, and using a three-dimensional equity analysis framework, we provide insights on the equity challenges associated with the implementation of community forestry in Cameroon over the past 20 years.

\section{CONCEPTUAL FRAMEWORK FOR EQUITY ANALYSIS IN COMMUNITY FORESTRY}

Although discussions about global environmental governance reflect the centrality of equity to just and sustainable outcomes, equity and its components are still not clearly defined (McDermott et al. 2013). Equity in the context of resource management has been previously discussed by Mahanty et al. (2006), McDermott (2009a, b), McDermott et al. (2013), and Turner et al. (2016). Equity is linked to a fair share among stakeholders of socioeconomic benefits derived from resource management. The effort and role of stakeholders in the resource management system, their social context, and the existing norms and values need to be considered in the discussion related to equity (Mahanty et al. 2006). Said otherwise, it relates to who pays and benefits from resource management (Maryudi et al. 2012). Equity also refers to the existing power relationship among intervening stakeholders (Agarwal 2001). Further, McDermott et al. (2013) suggested that an equitable share differs from an equal share. Equality means giving the same benefits to all and equity means the poorest obtaining more benefits than the richer with the aim of reducing the gap between the poor and the rich within a community. Therefore, as pointed out by Schreckenberg and Luttrell (2009), an equitable share of benefits requires among others, a strong focus on good governance (including well-being ranking to identify the poorest, empowerment classes for women, and public audits) that will gradually lead to decision making that responds more directly to the needs of marginalized groups. Also, what is meant by equity significantly depends on the context and perception of what is fairness by those analyzing it (Di Gregorio et al. 2013, Wong et al. 2016). The meaning of equity sometimes differs significantly between countries and between different cultural contexts within countries (Costenbader 2015). Equity also differs between civil societies, national, and international actors (Di Gregorio et al. 2013). Also, Mahanty et al. (2006) suggested that because cultures are dynamic, so might be the stakeholder philosophy on equity as ideas and demands change over time. We adopt the view of equity as a fair redistribution of forests benefits in an environment in which transparency, representation, and participation of all stakeholders in decision making are effective, and the interest of vulnerable groups protected.

McDermott et al. (2013) proposed three inter-related dimensions of equity: distributive, procedural, and contextual. Distributive equity addresses the outcomes of resource management (allocation of costs and benefits); procedural equity refers to decision making, i.e, the process by which actions are formulated and implemented (Mahanty et al. 2006, Di Gregorio et al. 2013, McDermott et al. 2013). It includes participation, recognition, and representation (Costenbader 2015). Contextual equity combines distributive and procedural equity (Agrawal and Gupta 2005, Sherpa and Brower 2015) and recognizes that the pre- 
existing social, political, and economic conditions in a community can limit or facilitate people's access to decision-making procedures, resources, benefits, and contribute to the degree of (in)equity prevailing (McDermott et al. 2013, Sherpa and Brower 2015). For instance, according to Agrawal and Gupta (2005), those with economic and social advantages are more likely to participate in decision-making processes, allowing them to shape decisions in a way that benefits them and guarantees them a high economic profit at the expense of the rest of the society. Further, as shown by Ekoko (2000), when only the most influential groups are actively involved in policy reforms, they ensure laws and regulations are formulated to suit their interests.

The main equity elements discussed in literature and reported by McDermott et al. (2013), Di Gregorio et al. (2013), and Costenbader (2015) include tenure and resources rights, benefit sharing, participation, access to information, governance (crosscutting issue relevant to all the above), gender, livelihoods, and grievance mechanisms (interrelated with the above elements). Nevertheless, these issues do not receive the same level of attention from scholars and other stakeholders. For instance, cost and benefit distribution appear to be the most prominent equity issue discussed (Di Gregorio et al. 2013, Sherpa and Brower 2015, Wong et al. 2016). Also, although livelihoods, tenure, and rights (including recognition of local rights) are frequently discussed, other issues like gender, sovereignty, and participation are given less consideration despite the widespread criticism of the lack of effective participation by local forest users in the literature (Di Gregorio et al. 2013, Costenbader 2015). Furthermore, these elements can be grouped under the three dimensions of equity as shown in Figure 1. Distributive equity encompasses tenure and resource rights, and benefit/cost sharing; procedural equity includes community participation and decision making, access to information and grievance mechanisms; and contextual equity comprises governance and regulations, livelihoods, gender equity, social and economic inequality, and treatment of poor and indigenous/minority populations (Costenbader 2015).

Fig. 1. The three interdependent dimensions of equity and their constitutive elements.

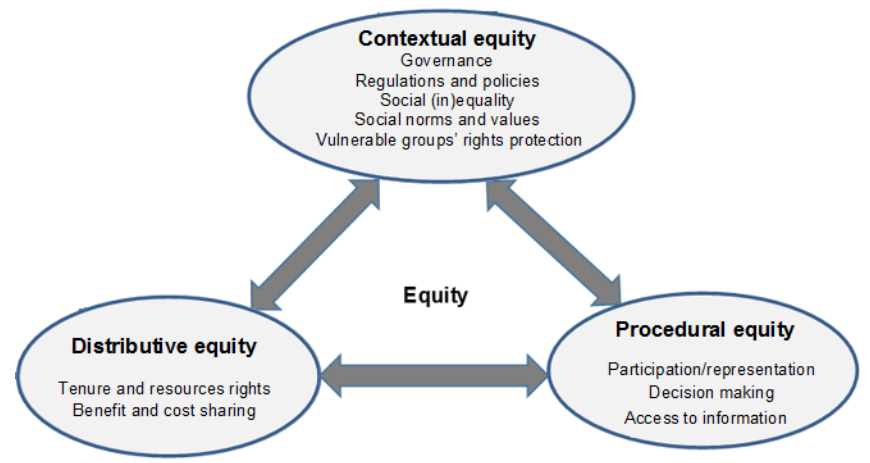

We adopt the view that the three dimensions of equity are interdependent and should be considered together to achieve equitable outcomes (McDermott et al. 2013, Sherpa and Brower 2015). Thus, all these elements will be discussed in relation to community forestry in Cameroon. Moreover, we will frequently call on contextual equity elements that are cross-cutting to discuss in detail issues related to distributive and procedural equity. Therefore, to avoid repetition, there will be no specific section discussing contextual equity. Figure 1 presents the dimensions of equity and their elements as used in this study.

\section{EQUITY CHALLENGES IN COMMUNITY FORESTRY IMPLEMENTATION IN CAMEROON}

Factors limiting equity in access and rights to forests resources and forests benefits distribution

Insecure tenure, discriminatory, and limited resource use rights Brown (1999) claimed that with no legal basis in Cameroon, the notion of "community" in the term "community forest" makes unclear the nature of the community into whose hands the management of the community forest is placed. Thus, the notion is open to interpretation on a variety of grounds among which residential, ethnic, and associational (Brown and Schreckenberg 2001). This leads to conflict between neighboring communities regarding who owns the community forest and who should benefit from the revenue generated from its exploitation (Cuny 2011, Ezzine de Blas et al. 2011). Though community forest creation is sometimes motivated by NGOs, the initiative usually comes from local elites and traditional rulers. However, in practice, there is often an appropriation by the latter two (Oyono et al. 2007) who sometimes refer to the community forests as "my forest." Therefore, it is unlikely that in such community forests, all the community members are entitled to the same rights regarding the use of the forest, its benefits, and nor do they all effectively participate or influence decisions regarding its management.

The forestry law in Cameroon provides communities with rights and responsibilities over forest resources (Mbile et al. 2009, Oyono 2009). These include

1. Use/withdrawal rights for individual and community consumption and subsistence: gathering of nontimber forest products, hunting, fishing, collection of minor timber products for housing, agriculture, etc.

2. Access rights: access to community forests and the nonpermanent forest estate.

3. Management rights: exploitation of plots in community forests according to simple management plans, monitoring of exploitation activities, and regeneration activities planned.

4. Exclusive rights: exclusion of members of other village communities from community forests.

5. Trade rights: marketing of timber and nontimber forest products derived from the exploitation of community forests, promotion of ecotourism, community management of financial revenue accruing from the marketing of products and ecotourism.

Nonetheless, as suggested by Oyono (2009), despite the goodwill of the government, the most important and strongest set of rights claimed by local communities, i.e., ownership or alienation rights, does not figure in the present forestry law. The granting of a community forest is not final and irrevocable in terms of temporal, legal, and administrative considerations (Cuny 2011). If a 
community forest is poorly managed, the management agreement can be suspended and the forest concerned withdrawn by the state (Oyono 2009, Cuny 2011). The law, however, does not provide any details about what is considered to be poor management. As such, allows for forestry administration officials and other local administrative authorities to use their power and influence to obtain financial incentives and other benefits from community members. Moreover, Oyono et al. (2007) suggest that this incomplete and conditional transfer of forest management rights and ownership to communities makes local managers upwardly accountable to municipal authorities, regional administrative authorities, NGOs, representatives of forestry administration, logging companies, etc. rather than to village communities. This, therefore, constitutes a barrier to local freedom in decision making.

Communities' rights are constrained to the nonpermanent forest domain. The latter is smaller and not a very strategic space to create significant forest revenue compared to the strategic forest block, i.e., the permanent forest domain, with tree species of high commercial value that remain totally controlled by the government (Mandondo 2003). Thus, just as in many countries in which governments have handed over forest ownership or management to communities, they have tended to only give up control of the poorest quality woodlands (Lawrence 2007). Cameroon's forest zoning was designed to benefit the state at the disadvantage of communities. In addition, although community forestry is more inclined to support sustainable management of forest resources (Mbile et al. 2009, Merlet and Fraticelli 2016), Cameroon has made an obvious choice to favor industrial logging companies in its forest policy. For instance, although the area covered by a community forest cannot exceed 5000 hectares, the forests intended for concessions and commercial logging can be up to 200,000 hectares (Oyono 2009, Cuny 2011). Moreover, the actual surface of valid community forests is significantly smaller than that of concessions and councils' forests (Cerutti et al. 2016). The summary of Cameroon's forest estate in December 2014 published by the Ministry of Forestry and Wildlife and by the World Resources Institute records 392 community forests covering just about 1.3 million hectares compared to 6.7 and 4.7 million hectares of forest assigned to forest management units and protected areas. Therefore, the benefits communities can receive from the forest is limited and reduced compared to that of private actors.

Within production forest, local populations' usage rights to NTFPs are normally protected if they do not affect endangered species and are not for commercial use. On the ground, things often happen very differently, with forestry production having priority over local populations' usage rights (Merlet and Fraticelli 2016). On the one hand, this can significantly impact poor households' livelihoods, especially women. The latter depends heavily on NTFPs, which provide them with food, medicine, fodder, and nonfarm income (Awono et al. 2016). On the other hand, because men are mainly involved in cash crop activities and timber exploitation within the forest, the impact is less significant on them (Oyono et al. 2007). Furthermore, tenure insecurity does not motivate people to invest in sustainable land-use practices (Holden and Otsuka 2014) and can be critical to food security, livelihood opportunities, and poverty reduction (Gyau et al. 2014). Tenure insecurity can also lead to conflicts, instability, and the exclusion of vulnerable groups, such as women and indigenous people (ILC 2014). Nevertheless, Gregersen and Contreras (2010) as cited by Beauchamp and Ingram (2011) pointed out that classic tenure rights are not actually a guarantee of sustainable management. What matters is considering the existing customary and regulatory frameworks to ensure local level empowerment and institution building (Fomété and Vermaat 2001, Gregersen and Contreras 2010).

\section{Cost and governance structures favoring unfair redistribution of} forest benefits

The process and costs related to community forests allocation and acquisition contribute to limit most community members' chances of deriving substantial benefit from their already limited rights. This constitutes a fertile ground for continual abuses and misappropriation of forest benefits by state officials, elites, and logging companies. Indeed, the choice, application for, and acquisition of a legal status, as well as the preparation of an application file and the simple management plan required for a community forest allocation are financially and technically demanding in terms of resources. Most of the concerned communities are unlikely to possess such resources (Brown and Schreckenberg 2001, Djeumo 2001, Boutinot et al. 2016, Rainforest Alliance 2016). Mbile et al. (2009) estimated these costs at between US $\$ 12,000$ and US $\$ 24,000$ while USAID (2011) estimated them to be up to US\$55,000. Therefore, most often, communities must develop formal or informal partnerships with other actors to have sufficient resources to complete the process (Djeumo 2001). Though this can generate significant downstream returns (Brown and Schreckenberg 2001), it has been shown that it contributes to the danger of capture by community elites (Brown and Schreckenberg 2001, Oyono 2009, Rainforest Alliance 2016) and creates opportunities for logging companies to get into the process (Djeumo 2001, Boutinot et al. 2016). Indeed, in some areas, many initiatives are financed by logging companies based on contracts signed with communities that confer them the right to exploit the timber in the community's forests once they are allocated (Djeumo 2001, Cuny 2011). However, previous studies (Auzel et al. 2001, Cuny 2011, Ezzine de Blas et al. 2009, 2011, Merlet and Fraticelli 2016) suggest that due to insufficient government checks and extensive corruption, logging companies do not usually respect the exploitation rules set in the simple management plan of the community forest. As such, they end up overexploiting the forest. Moreover, the communities only receive a small part of the profits generated by the forest and are left at the end with a forest empty of all its highvalue trees (Auzel et al. 2001, Cuny 2011, Ezzine de Blas et al. 2011, Merlet and Fraticelli 2016). This practice also has a cost for the state because the companies use the community forest to avoid regulatory constraints on the concessions including the requirement for management plans. They also often evade taxes when they operate under the umbrella of community forests because the latter are not expected to pay taxes (Fomété and Vermaat 2001, Oyono et al. 2006, Mvondo 2006, Karsenty 2007, Morrison et al. 2009, USAID 2011, Merlet and Fraticelli 2016).

Furthermore, even when a community exploits its forest, high transaction costs are found along the value chain accruing from its exploitation (Mbile et al. 2009, Foundjem-Tita et al. 2014). The high transaction costs generally result from the lack of market information, the long distance to markets, and high 
transportation costs (Ezzine de Blas et al. 2009). This might explain the low incentive for market-oriented activities, inefficient exploitation of the forest resources, and the low net benefits derived from forests by local communities observed on the ground. Therefore, external actors such as an NGO can play a significant role in tackling these issues by supporting communities with technical and financial resources that communites usually lack (Ezzine de Blas et al. 2009). Indeed, providing external support to people from the establishment of the community forest to its exploitation can help achieve a high degree of vertical integration and thus increase the rents captured by people from their forest (Ezzine de Blas et al. 2009, Beauchamp and Ingram 2011). The extra payments may be both in terms of net timber revenues and labor-related income (Ezzine de Blas et al. 2009). Nevertheless, as highlighted by Beauchamp and Ingram (2011), external supports do not always correlate with positive outcomes and can be detrimental and costly if insufficient and can also create dependency. Thus, it is crucial to ensure community forests receive adequate support while ensuring they do not become dependent on external supports.

In communities in which the forest is effectively exploited, there are challenges regarding the redistribution of the benefits between community members. An analysis of the first communities to obtain community forests in Cameroon by Fomété and Vermaat (2001) showed that benefits sharing ranged from distribution on an individual basis to more complex arrangements. The latter generally considers community diversity and often results in significant multiplier effects for the whole community. According to Merlet and Fraticelli (2016), in Cameroon, incomes from community forests are usually monopolized by a minority of players and not redistributed to communities. This is supported by Ezzine de Blas et al. (2011) who studied 20 community forests in Cameroon. They found that $76 \%$ of the money earned by these community forests was distributed among specific actors or interest groups. Only $24 \%$ was invested in community development projects as specified in community forests simple management plans. Similarly, Cuny (2011) estimated the share of benefits used for community development at $16 \%$; the rest being shared among the management committee members, forestry administration, and local administrative authorities. In fact, as observed by Oyono et al. (2006), many community forests in Cameroon still have no explicit, structured, internal regulations to guide the management of the income from the community forest. Consequently, forest people only get benefits from the community forest when the management committee decides to invest or share the money earned from forest exploitation. This practice often leads to conflict at the community level (Djeumo 2001, Fomété and Vermaat 2001, Cuny 2011, Ezzine de Blas et al. 2011). In such circumstances, women and youths, because of existing cultural values and norms, are more vulnerable and susceptible to receive little or no benefit.

When logging companies have contracts with communities, Mbatu (2012) and Merlet and Fraticelli (2016) observed that what is received from companies by communities in terms of payments, direct contributions in kind, and social benefits (roads, schools, hospital, etc.) is often insignificant compared to what is specified in the contracts. Moreover, as stipulated by Oyono et al. (2007), local communities are seldom involved in negotiations and decision making about socioeconomic amenities to be established at the village level. Mbatu (2012) indicated that deals with loggers are usually made to benefit only powerful elites and not the community. As suggested by Merlet and Fraticelli (2016), these observations might be explained by the gaps in the existing laws. In fact, one of the objectives targeted by the Government of Cameroon in the 1994 Forestry Law, is to involve forest-dependent people in managing forest resources and to enable these groups to obtain substantial benefit from it. However, the law did not put enough mechanisms in place to ensure the forest is managed equitably and sustainably with the effective participation of all stakeholders.

\section{Stakeholders' relationships, decision making, information flow,} and barriers to procedural equity

Participation, representation, and decision making in community forestry management

Community forests allocation process can last for up to four years (Cuny 2011) and is described as long and complicated by communities (Auzel et al. 2001, Cuny 2011, USAID 2011, Rainforest Alliance 2016). This lengthy process is sustained by unethical practices. For instance, the signature of the management agreement and its renewal need the decisional involvement of many local-level civil servants who sometimes try to gain rents out of the process (Oyono 2009). In most cases, community forest initiators in Cameroon are nonresident elites. These elites often use their relationships within the central government, superior knowledge of administrative procedures, and financial resources to comply with the requirements set by the central administration. Occasionally, these external elites work in tandem with internal elites such as the traditional authorities to whom they offer responsibilities in the community forest management committees (Djeumo 2001, Cuny 2011, Oyono 2009, Merlet and Fraticelli 2016). Many of these community forest management committees operate without full community participation and lack transparency and downward accountability, especially regarding decision making about the management of community forest revenue. Consequently, most benefits from community forest are captured by local elites (Mvondo 2006, Oyono et al. 2006, 2007, Karsenty 2007, USAID 2011, Merlet and Fraticelli 2016). Indeed, these management bodies are established without competitive election or democratic process. Co-optation and selfappointment are frequently used with no provision for sanctions in case of mismanagement (Oyono et al. 2007). The combination of the above therefore contributes to maintaining the status quo and to normalizing mismanagement of forest revenues.

Similarly, and from gender, rights, and power perspectives, these leaders also take advantage of local, cultural, and traditional values and norms that give priority to men, well-educated and wealthy community members to control the natural resources and the benefits accruing from it. Thus, women, youths, or generally poorer community members who do not possess the skills and competencies are unlikely to be represented and/or participate effectively in management committees and make their voices heard. These groups sometimes innocently believe that their elites are well placed and better educated to make decisions for the community, probably because of the convincing discourse of these elites who usually disguise their real intentions behind common community interests at the start of the project. Also, as claimed by Fométe (2001), some of the difficulties above can be 
attributed to the fact that many communities ignore the resources they are entitled to and their duties regarding the community forest management. Thus, he recommends the creation and maintenance of a transparent flow of information among all stakeholders involved in community forestry to increase local people participation in the overall process and improve forest governance in general.

\section{Access to information on law and procedures}

Diverse actors that do not necessarily share the same ideas and interests regarding forestland policies intervene in the community forestry in Cameroon (Cuny 2011, Ongolo 2015, Djiegni et al. 2016). Communities, public sector, private enterprises, and local, national, and international NGOs, among others compete for the various policies that are designed to satisfy their desires. Mbatu (2012) observed little or no flow of information between these different stakeholders. However, to assist communities and other stakeholders, in Cameroon, the Ministry of Forest and Wildlife published The Manual of the Procedures for the Attribution, and Norms for the Management of Community Forests in 1998. The manual describes the standards and procedures concerning the presentation and the processing of applications for community forests. It further defines the minimum consultation procedures required for the legal allocation of a community forest (Fomété and Vermaat 2001). A revised version of the manual was published in 2009. In practice, although the manual is available, it has not been largely distributed and most communities are not aware of its existence (Beauchamp and Ingram 2011). Furthermore, most forest inhabitants are illiterate and the few who can read and write find it difficult to understand and interpret policy documents (Mbatu 2012). Therefore, communities are likely to be dependent vis-à-vis external actors and more vulnerable to greedy loggers and government official imposters, putting their rights at risks. Ensuring that forest people have access to all relevant regulatory information can increase their capacity to influence decision making and to effectively manage their forests. Sufficient access to information can provide safeguards against external abuse and elite capture, and can ensure equitable benefit sharing and informed community planning (Beauchamp and Ingram 2011, Fomété and Vermaat 2001).

\section{CONCLUSION AND RECOMMENDATIONS}

After reviewing some of the existing literature addressing equity in community forestry in Cameroon over the past 20 years, we concluded that: a lack of clarity of the Cameroon forestry law vis-à-vis who the "community" refers to in the term "community forest"; an inequitable distribution of forest resources between the permanent forest (richer) and the nonpermanent forest domain (poorer and to which community forests belong); the cost associated with the community forest allocation process; corruption, illegal, and unethical behavior in the private sector; and the insufficient technical and financial capacities of communities, have prevented community forestry from making a significant contribution to the country's development, sustainable forest management, and equitable improvement in forest people's well-being.

Moreover, the review points out that, although in theory community forestry is aimed at increasing local people's access to forest revenues, in Cameroon, political and administrative elites, sometimes in collaboration with logging companies, have taken advantage of the weak internal organizational capacity of forest communities to misappropriate the highest share of the revenues generated by community forests at the detriment of local people. It can also be said that most issues related to distributive and procedural equity can be attributed to the poorly structured socioeconomic and legal environment within which community forestry in Cameroon is implemented.

The increasing interest of communities and governments in community forests calls for a better understanding of conditions required for a sustainable, profitable, and equitable management of forest resources and benefits. The study revealed that many studies have questioned the concept of community forestry as defined in the law (Brown 1999, Ekoko 2000, Brown and Schreckenberg 2001, Cuny 2011, Ezzine de Blas et al. 2011). This means that regarding contextual equity, a clear definition of "community" is required to allow local populations to develop appropriate representation and accountability through legitimate and accountable institutions. Cameroon could learn from the Democratic Republic of Congo where the forest law specifically defines a community as "a population traditionally organized on the basis of custom and united by bonds of solidarity in a clan or a kin, underpinning its internal cohesion [...] characterized by its attachment to a particular land" (Vermeulen and Karsenty 2017:3). Such a definition is necessary to socially and legally position the entity in charge of managing the forest on behalf of the community. A transfer without conditionality of forest management rights to communities and an extension of their rights to the richer part of the forestlands by the state is also required to enhance distributive equity. Those in charge of managing the forest on behalf of the community should be democratically elected by all community members. This could improve procedural and distributive equity by building a strong sense of community ownership, reducing disparities, and limiting the risk of rents capture.

Several factors such as the technical and managerial capacities of communities, access to and the quality of natural resources, access to finance, and legal resources can highly influence the profitability and distribution of benefits within a community forest (Beauchamp and Ingram 2011). Thus, community forests should be empowered to develop sustainable forest management plans, apply best forestry practices, strengthen their administrative and organizational capacities, and invest in strategies that add value to their products and enable them to penetrate premium markets for wood and other forest products. Improving transportation infrastructure and community access to market information could reduce transaction cost, facilitate market access, and help communities to move toward greater vertical integration. Promoting and strengthening communitybased financial and credit systems could enable communities to fund their community forest independently of external supports. The design of benefits-sharing mechanisms that prioritize the most vulnerable and forest-dependent groups, such as women, is needed to reduce gender and social inequality. The role and influence of the vulnerable and less represented in decision making should be increased to improve on procedural equity. More collaboration, cooperation, transparency, and information flow among the various stakeholders, and the setting of mechanisms that ensure the respect of forest policy provisions and its monitoring could be useful for this purpose. Finally, 
continued legislative and institutional reforms are needed to bring about these improvements in community forestry. These strategies could help in achieving a high degree of distributive, contextual, and procedural equity, and also contribute to sustainable forest management, increase forest incomes, and improve forest people's livelihoods. Decentralization has proven its ability to increase justice and equity by increasing community participation. Thus, future research should investigate: (1) the readiness of the central government to effectively transfer management competencies to communities, and (2) the profitability and sustainability of economic activities undertaken by community forest enterprises. Also, the meaning "equity" among the different community forestry stakeholders in the Cameroonian context needs to be known. This is necessary to effectively and efficiently support them in the design of more equitable policies and benefit-sharing mechanisms.

Responses to this article can be read online at: http://www.ecologyandsociety.org/issues/responses. php/10656

\section{Acknowledgments:}

The authors are grateful to UK Aid Department for International Development for funding this research through the project Financing Sustainable Community Forest Enterprises in Cameroon. We thank the anonymous reviewers for their constructive and insightful comments and suggestions to improve the quality of the paper. The authors are also grateful to the colleagues who helped to edit the last version of this paper.

\section{LITERATURE CITED}

Agarwal B. 2001. Participatory exclusions, community forestry, and gender: an analysis for South Asia and a conceptual framework. World Development 29(10):1623-1648.

Agrawal, A., and K. Gupta. 2005. Decentralization and participation: the governance of common pool resources in Nepal's Terai. World Development 33(7):1101-1114. http://dx.doi. org/10.1016/j.worlddev.2005.04.009

Andersson, K. P., C. C. Gibson, and F. Lehoucq. 2006. Municipal politics and forest governance: comparative analysis of decentralization in Bolivia and Guatemala. World Development 34(3):576-595. http://dx.doi.org/10.1016/j.worlddev.2005.08.009

Atyi Eba'a, R., N. J. Poufoun, J.-P. Mvondo Awono, A. N. Manjeli, and R. S. Kankeu. 2016. Economic and social importance of fuelwood in Cameroon. International Forestry Review 18(1):52-65. http://dx.doi.org/10.1505/146554816819683735

Auzel, Ph., G. M. Nguenang, R. Feteké, and W. Delvingt. 2001. Small-scale logging in community forests in Cameroon: towards ecologically more sustainable and socially more acceptable compromises. Rural Development Forestry Network paper. Overseas Development Institute, London, UK. [online] URL: https://www.odi.org/sites/odi.org.uk/files/odi-assets/publicationsopinion-files/1224.pdf

Awono, A., R. Atyi Eba'a, D. Foundjem-Tita, and P. Levang. 2016. Vegetal non-timber forest products in Cameroon, contribution to the national economy. International Forestry Review 18(1):66-77. http://dx.doi.org/10.1505/146554816819683708

Beauchamp, E., and V. Ingram. 2011. Impacts of community forests on livelihoods in Cameroon: lessons from two case studies. International Forestry Review 13(4):389-403. http://dx.doi. org/10.1505/146554811798811371

Boutinot, L., P. Karpe, O. I. Mandjek, V. Fache, and G. P. Dkamela. 2016. La gestion participative des forêts au service de l'amélioration des conditions de vie des populations locales vers la création d'un espace de développement commun? Pages 63-77 in G. Buttoud and J.-C. Nguinguiri, editors. La gestion inclusive des forêts d'Afrique centrale: passer de la participation au partage des pouvoirs. FAO and CIFOR, Libreville, Gabon and Bogor, Indonesia. [online] URL: http://www.cifor.org/publications/ pdf_files/Books/FAO-CIFOR_Book.pdf

Brown, D. 1999. Principles and practice of forest co-management: evidence from West-Central Africa. European Union Tropical Forestry Paper 2. Overseas Development Institute, London, UK. [online] URL: https://www.odi.org/sites/odi.org.uk/files/odiassets/publications-opinion-files/5688.pdf

Brown, D., and K. Schreckenberg. 2001. Community forestry: facing up to the challenge in Cameroon. Rural Development Forest Network paper. Overseas Development Institute, London, UK. [online] URL: https://www.odi.org/sites/odi.org.uk/files/odiassets/publications-opinion-files/1206.pdf

Cerutti, P. O., M. Mbongo, and M. Vandenhaute. 2016. State of the timber sector in Cameroon (2015). FAO/CIFOR, Food and Agriculture Organization of the United Nations/Center for International Forestry Research, Rome, Italy/Bogor, Indonesia. [online] URL: http://www.cifor.org/publications/pdf files/reports/ FAO Report EN.pdf

Chao, S. 2012. Forest peoples: numbers across the world. Forest Peoples Programme, Moreton-in-Marsh, UK. [online] URL: http://www.forestpeoples.org/sites/fpp/files/publication/2012/05/forestpeoples-numbers-across-world-final 0.pdf

Collins, F., and R. Tsanga. 2016. Community forestry in Central Africa: has it been a success? Center for International Forestry Research, Bogor, Indonesia. [online] URL: http://foreststreesagroforestry. org/community-forestry-in-central-africa-has-it-been-a-success/

Costenbader, J. 2015. Equity in forests and REDD+: an analysis of equity challenges as viewed by forestry decision-makers and practitioners in Cambodia, Lao PDR and Viet Nam. Regional Community Forestry Training Center for Asia and the Pacific (RECOFTC) - The Center for People and Forests, Bangkok, Thailand. [online] URL: https://www.recoftc.org/sites/default/ files/public/publications/resources/recoftc-0000144-0001-en.pdf

Cuny, P. 2011. Etat des lieux de la foresterie communautaire et communale au Cameroun. Tropenbos International Programme $\mathrm{du}$ bassin du Congo, Wageningen, The Netherlands. [online] URL: https://www.tropenbos.org/file.php/547/etatsdeslieux-28-12-2011. pdf

Di Gregorio, M., M. Brockhaus, T. Cronin, E. Muharrom., L. Santoso, S. Mardia, and M. Büdenbender. 2013. Equity and REDD+ in the media: a comparative analysis of policy discourses. Ecology and Society 18(2):39. http://dx.doi. org/10.5751/ES-05694-180239 
Djeumo, A. 2001. The development of community forests in Cameroon: origins, current situation and constraints. Rural Development Forest Network paper. Overseas Development Institute, London, UK. [online] URL: https://www.odi.org/sites/ odi.org.uk/files/odi-assets/publications-opinion-files/1208.pdf

Djiegni, F. K., S. Assembe-Mvondo, R. Eba'a Atyi, P. Levanga, and T. Fomété. 2016. Cameroon's forest policy within the overall national land use framework: from sectorial approaches to global coherence? International Forestry Review 18(1):4-13. http://dx. doi.org/10.1505/146554816819683762

Ekoko, F. 2000. Balancing politics, economics and conservation: the case of the Cameroon forestry law reform. Development and Change 31(1):131-154. http://dx.doi.org/10.1111/1467-7660.00149

Ezzine de Blas, D., M. Ruiz-Pérez, J. A. Sayer, G. Lescuyer, R. Nasi, and A. Karsenty. 2009. External influences on and conditions for community logging management in Cameroon. World Development 37(2):445-456. http://dx.doi.org/10.1016/j. worlddev.2008.03.011

Ezzine de Blas, D., M. Ruiz-Pérez, and C. Vermeulen. 2011. Management conflicts in Cameroonian community forests. Ecology and Society 16(1):8. http://dx.doi.org/10.5751/ES-03845-160108

Fomété, T. 2001. The forestry taxation system and the involvement of local communities in forest management in Cameroon. Rural Development Forest Network paper. Overseas Development Institute, London, UK. [online] URL: https://www.odi.org/sites/ odi.org.uk/files/odi-assets/publications-opinion-files/1210.pdf

Fomété, T., and J. Vermaat. 2001. Community forestry and poverty alleviation in Cameroon. Rural Development Forest Network paper. Overseas Development Institute, London, UK. [online] URL: https://www.odi.org/sites/odi.org.uk/files/odi-assets/publicationsopinion-files/1232.pdf

Food and Agriculture Organization of the United Nations (FAO). 2014. State of the world's forests: enhancing the socioeconomic benefits from forests. FAO, Rome, Italy. http://www.fao.org/3/ai3710e.pdf

Foundjem-Tita, D., S. Speelman, M. D’Haese. A. Degrande, G. Van Huylenbroeck, P. Van Damme, and Z. Tchoundjeu. 2014. A tale of transaction costs and forest law compliance: trade permits for non-timber forest forests products in Cameroon. Forest Policy and Economics 38:132-142. https://doi.org/10.1016/j.forpol.2013.08.007

Gregersen, H., and A. Contreras. 2010. Rethinking forest regulations. From simple rules to systems to promote best practices and compliance. Rights and Resources Initiative, Washington, D. C., USA. [online] URL: http://citeseerx.ist.psu.edu/viewdoc/ $\underline{\text { download?doi }=10 \cdot 1 \cdot 1 \cdot 378.1776 \& \text { rep }=\text { rep } 1 \& \text { type }=p d f}$

Gyau, A., A. N. Faith, D. Foundjem-tita, N. Ajaga, and D. Catacutan. 2014. Small-holder farmers' access and rights to land: the case of Njombé in the Littoral region of Cameroon. Afrika Focus 27:23-39. [online] URL: https://ojs.ugent.be/AF/article/ view/4905/4840

Holden, S. T., and K. Otsuka. 2014. The roles of land tenure reforms and land markets in the context of population growth and land use intensification in Africa. Food Policy 48:88-97. https://doi.org/10.1016/j.foodpol.2014.03.005 http://dx.doi.org/10.1016/ j.foodpol.2014.03.005
International Fund for Agricultural Development (IFAD). 2004. Commerce et développement rural: enjeux et perspectives pour les ruraux pauvres. IFAD, Rome Italy.

International Land Coalition (ILC). 2014. Promoting peoplecentred land governance-Cameroon. International Land Coalition, Rome, Italy. [online] URL: http://www.landcoalition. org/sites/default/files/documents/resources/cameroon_country_strategy. pdf

Jum, C., J. Nguiebouri, M. Zoa, and C. Diaw. 2007. The model forest experience in Cameroon. ITTO Tropical Forest Update 17 (2):11-14

Karsenty, A. 2007. Overview of industrial forest concessions and concession-based industry in central and west Africa and considerations of alternatives. CIRAD, Paris, France. [online] URL: http://agritrop.cirad.fr/542167/1/document 542167.pdf

Lawrence, A. 2007. Beyond the second generation: towards adaptiveness in participatory forest management. Perspectives in Agriculture, Veterinary Science, Nutrition and Natural Resources 2(28):1-15. http://dx.doi.org/10.1079/PAVSNNR20072028

Lescuyer, G. 2010. Importance économique des produits forestiers non ligneux dans quelques villages du Sud Cameroun. Bois et Forêts des Tropiques 304(2):15-24. http://dx.doi. org/10.19182/bft2010.304.a20442

Logo, P.B. 2003. The decentralized forestry taxation system in Cameroon: local management and state logic. Environmental Governance in Africa Working Paper Series (WRI) No.10. World Resources Institute, Washington, D.C., USA. [online] URL: https://cgspace.cgiar.org/handle/10568/18703

Mahanty, S., J. Fox, L. McLees, M. Nurse, and P. Stephen. 2006. Introduction: equity in community-based resources management. Pages 1-13 in S. Mahanty, J. Fox, L. McLees, M. Nurse, and P. Stephen, editors. Hanging in the balance: equity in communitybased natural resource management in Asia. Regional Community Forestry Training Center for Asia and the Pacific (RECOFTC), Bangkok, Thailand and East-West Center, Honolulu, Hawaii, USA. [online] URL: http://www.eastwestcenter.org/fileadmin/ stored/misc/HangingInBalance02Introduction.pdf

Mandondo, A. 2003. Snapshot views of international community forestry networks: Cameroon country study. CIFOR-Yaoundé, Yaoundé, Cameroon. [online] URL: http://citeseerx.ist.psu.edu/ viewdoc/download;jsessionid=A2DC697E1F82EEC87C654DC$\underline{\mathrm{A} 75025187 \text { ?doi }=10.1 .1 .513 .8778 \& \mathrm{rep}=\text { rep1\&type }=\text { pdf }}$

Maryudi, A., R. R. Devkota, C. Schusser, C. Yufanyi, M. Salla, H. Aurenhammer, R. Rotchanaphatharawit, and M. Krott. 2012. Back to basics: considerations in evaluating the outcomes of community forestry. Forest Policy and Economics 14(1):1-5. http:// dx.doi.org/10.1016/j.forpol.2011.07.017

Mbatu, R. S. 2012. Obstacles to a conceptual framework for sustainable forest management under REDD in Central Africa: a two-country analysis. Pages 27-50 in J. Martín-García and J. J. Diez, editors. Sustainable forest management-case studies. InTech, London, UK. http://dx.doi.org/10.5772/28988

Mbile, P., A. G. Ndzomo, H. Essoumba, and A. Minsouma. 2009. Alternate tenure and enterprise models in Cameroon: community forests in the context of community rights and forest landscapes. 
Strategy paper. Rights and Resources Initiative, Washington, D. C., USA. [online] URL: http://www.rightsandresources.org/wpcontent/exported-pdf/cameroonenglish.pdf

McDermott, M. H. 2009a. Equity first or later? How US community-based forestry distributes benefits. International Forestry Review 11:207-220. http://dx.doi.org/10.1505/ifor.11.2.207

McDermott, M. H. 2009b. Locating benefits: decision-spaces, resource access and equity in US community-based forestry. Geoforum 40:249-259. http://dx.doi.org/10.1016/j.geoforum.2008.10.004

McDermott, M. H., S. Mahanty, and K. Schreckenberg. 2013. Examining equity: a multidimensional framework for assessing equity in payments for ecosystem services. Environmental Science and Policy 33:416-427. http://dx.doi.org/10.1016/j.envsci.2012.10.006

Merlet, M., and M. Fraticelli. 2016. Protecting forests, improving livelihoods: comparing community forestry in Cameroon and Guatemala. Fern, Moreton in Marsh, UK. [online] URL: http:// www.agter.org/bdf/ docs/fern forestry cam-guat internet.pdf

Ministry of Forestry and Wildlife (MINFOF) and Word Resources Institute. 2015. Cameroon's forest estate. MINFOF, Yaounde, Cameroon. [online] URL: http://data.globalforestwatch. org/datasets/8acec5f9baa54d52b8a5a292bdbc6dc2

Morrison, K., P. O. Cerutti, P. R. Oyono, and M. Steil. 2009. Broken promises: forest revenue sharing in Cameroon. WRI Forest Notes. World Resources Institute, Washington, D.C., USA. [online] URL: http://pdf.wri.org/broken_promises forestrevenue sharing in cameroon.pdf

Mvondo, S. A. 2006. Forestry income management and poverty reduction: empirical findings from Kongo, Cameroon. Development in Practice 16(1):68-73. http://dx.doi. org/10.1080/09614520500450867

Nkou, J. P., and R. Eba'a Atyi. 2013. Analyse macroéconomique du secteur forêt-faune. Pages 11-36 in R. Eba'a Atyi, G. Lescuyer, N. J. Poufom, and M. J. Fouda, editors. Étude de l'importance économique et sociale du secteur forestier et faunique au Cameroun. Center for International Forestry Research, Bogor, Indonesia. [online] URL: https://afrique-centrale.cirad.fr/content/ download/4439/34072/version/1/file/Etude+importance+\% $\% 3 \% \mathrm{~A} 9 \mathrm{co}+$ secteurs + for $\% \mathrm{C} 3 \%$ AAts + faune+au+Cameroun.pdf

Ongolo, S. 2015. On the banality of forest governance fragmentation: exploring "gecko politics" as a bureaucratic behaviour in limited statehood. Forest Policy and Economics 53:12-20. http://dx.doi.org/10.1016/j.forpol.2015.01.005

Oyono, P. R. 2009. New niches of community rights to forests in Cameroon: tenure reform, decentralization category or something else? International Journal of Social Forestry 2(1):1-23. [online] URL: http://www.cifor.org/tenure-reform/data/files/ cameroon/books_chapters_journal_articles/bcja_cameroon1.pdf

Oyono, P. R., J. C. Ribot, S. Assembe, and P. B. Logo. 2007. Improving decentralized forest management in Cameroon: options and opportunities from ten years of experience. Center for International Forestry Research. Bogor, Indonesia. http://dx.doi. org/10.17528/cifor/002190

Oyono, P. R., J. C. Ribot, and A. M. Larson. 2006. Green and black gold in rural Cameroon: natural resources for local governance, justice and sustainability. Working Paper Series:
Environmental governance in Africa. World Resources Institute, Washington, D.C., USA. [online] URL: http://pdf.wri.org/ oyonowri wp22.pdf

Parkins, J. R. 2006. De-centering environmental governance: a short history and analysis of democratic processes in the forest sector of Alberta, Canada. Policy Sciences 39:183-203. http://dx. doi.org/10.1007/s11077-006-9015-6

Poufoun, N. J., R. Eba'a Atyi, and P. Cerutti. 2013. Importance économique et sociale de l'exploitation industrielle du bois au Cameroun. Pages 39-67 in Eba'a Atyi R, G. Lescuyer, N. J. Poufom, and M. J. Fouda, editors. Étude de l'importance économique et sociale du secteur forestier et faunique au Cameroun. Center for International Forestry Research, Bogor, Indonesia. [online] URL: https://afrique-centrale.cirad.fr/content/ download/4439/34072/version/1/file/Etude+importance+\%C3\%A9co+ secteurs + for $\% \mathrm{C} 3 \%$ AAts + faune $+\mathrm{au}+$ Cameroun.pdf

Rainforest Alliance. 2016. Community forestry combats urgent threats in Cameroon. Rainforest Alliance, Amsterdam, The Netherlands. [online] URL: http://www.rainforest-alliance.org/ articles/community-forestry-combats-urgent-threats-in-cameroon

Republic of Cameroon. 1995. Decree No 95/531/PM of 23 August 1995 laying down the procedure for implementing the forest's system. Republic of Cameroon, Yaoundé, Cameroon. [online] URL: http://www.abs-initiative.info/fileadmin/user_upload/ Documents ICIPE/legal_texts/Legal_Cameroon_Decree 95_531_pm. pdf

Schreckenberg, K., and C. Luttrell. 2009. Participatory forest management: a route to poverty reduction? International Forestry Review 11(2):221-238. http://dx.doi.org/10.1505/ifor.11.2.221

Sherpa, D. T., and A. Brower. 2015. Equity in sharing the potential benefits of REDD+ in Nepal. Journal of Forest and Livelihood 13(1):20-29. http://dx.doi.org/10.3126/jfl.v13i1.15363

Turner, R. A., J. Addison, A. Arias, B. J. Bergseth, N. A. Marshall, T. H. Morrison, and R. C. Tobin. 2016. Trust, confidence, and equity affect the legitimacy of natural resource governance. Ecology and Society 21(3):18. http://dx.doi.org/10.5751/ ES-08542-210318

United State Agency for International Development (USAID). 2011. Property rights and resource governance-Cameroon. USAID country profile. United State Agency for International Development, Washington, D.C., USA. [online] URL: https:// www.land-links.org/wp-content/uploads/2016/09/ USAID Land Tenure Cameroon Profile.pdf

Vermeulen, C., and A. Karsenty. 2017. Towards a communitybased concession model in the DRC. International Forestry Review 19(2):80-86. http://dx.doi.org/10.1505/146554817822295894

Wong, G., M. Brockhaus, M. Moeliono, C. Padoch, and P. T. Thuy. 2016. Equity, REDD+ and benefit sharing in social forestry. Infobrief 142. Center for International Forestry Research, Bogor, Indonesia. [online] URL: http://www.cifor.org/publications/ pdf_files/infobrief/6127-infobrief.pdf

World Bank. 2016. World Bank Group Forest Action Plan FY16-20: the WBG contribution to the forest agenda. World Bank, Washington, D.C., USA. [online] URL: http://pubdocs. worldbank.org/en/190381459984535520/WBG-Forest-Action-PlanFY16-6apr16-CODE.pdf 